\title{
Defective skeletogenesis and oversized otoliths in fish early stages in a changing ocean
}

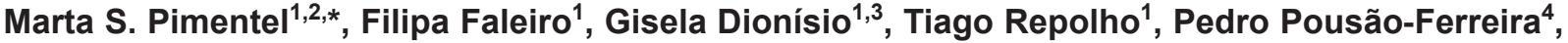 \\ Jorge Machado ${ }^{2}$ and Rui Rosa ${ }^{1}$
}

\begin{abstract}
Early life stages of many marine organisms are being challenged by rising seawater temperature and $\mathrm{CO}_{2}$ concentrations, but their physiological responses to these environmental changes still remain unclear. In the present study, we show that future predictions of ocean warming $\left(+4^{\circ} \mathrm{C}\right)$ and acidification $(\Delta \mathrm{pH}=0.5$ units) may compromise the development of early life stages of a highly commercial teleost fish, Solea senegalensis. Exposure to future conditions caused a decline in hatching success and larval survival. Growth, metabolic rates and thermal tolerance increased with temperature but decreased under acidified conditions. Hypercapnia and warming amplified the incidence of deformities by $31.5 \%$ (including severe deformities such as lordosis, scoliosis and kyphosis), while promoting the occurrence of oversized otoliths (109.3\% increase). Smaller larvae with greater skeletal deformities and larger otoliths may face major ecophysiological challenges, which might potentiate substantial declines in adult fish populations, putting in jeopardy the species' fitness under a changing ocean.
\end{abstract}

\section{KEY WORDS: Ocean warming, Acidification, Fish larvae, Ecophysiology, Skeletal deformities}

\section{INTRODUCTION}

Atmospheric carbon dioxide $\left(\mathrm{CO}_{2}\right)$ concentration has increased from pre-industrial levels of $280 \mu \mathrm{atm}$ to present-day levels of $394 \mu \mathrm{atm}$, and it is expected to rise to $730-1000 \mu \mathrm{atm}$ by the end of the century (Caldeira and Wickett, 2003; Meehl et al., 2007). Continuous $\mathrm{CO}_{2}$ uptake by the world's oceans is changing the seawater chemistry and is estimated to lead to a drop of $0.4-0.5$ units in seawater $\mathrm{pH}$ (Caldeira and Wickett, 2005). Concomitantly, the temperature of the oceans is rising, and global sea surface temperature is expected to increase $\sim 4^{\circ} \mathrm{C}$ by 2100 (Meehl et al., 2007), leading to profound impacts on marine ecosystems. In fact, the predictable rapid rate of climate change will induce thermal stress to coastal marine biota as their thermal tolerance limits are reached or even exceeded. Beyond a certain thermal limit, biological processes such as metabolism, growth, feeding, reproduction and behavior may be affected (Carmona-Osalde et al., 2004; Pörtner and Knust, 2007; Nilsson et al., 2009; Byrne, 2011; Pimentel et al., 2012; Rosa et al., 2012), thus compromising the overall fitness and survival of species.

${ }^{1}$ Laboratório Marítimo da Guia, Centro de Oceanografia, Faculdade de Ciências da Universidade de Lisboa, Av. Nossa Senhora do Cabo 939, 2750-374 Cascais, Portugal. ${ }^{2}$ Instituto Ciências Biomédicas Abel Salazar, Universidade do Porto Largo Prof. Abel Salazar 2, 4099-003 Porto, Portugal. ${ }^{3}$ Departamento de Biologia \& CESAM, Universidade de Aveiro, Campus Universitário de Santiago, 3810-193 Aveiro, Portugal. ${ }^{4}$ Instituto Português do Mar e da Atmosfera, Av. 5 de Outubro s/n 8700-305, Olhão, Portugal.

*Author for corresponding (mcrsilva@fc.ul.pt)

Received 17 June 2013; Accepted 11 March 2014
Additionally, under higher temperatures, marine organisms are likely to be more vulnerable to other environmental stressors such as ocean acidification (Pörtner, 2008; Byrne et al., 2010; Findlay et al., 2010; Parker et al., 2010; Sheppard Brennand et al., 2010; Byrne, 2011; Rosa et al., 2013; Rosa et al., 2014).

Ocean acidification is considered a major threat to marine organisms as it may lead to acid-base balance disturbances, protein biosynthesis decrease, metabolic depression and growth reduction (Seibel and Walsh, 2001; Pörtner et al., 2004; Langenbuch et al., 2006; Rosa and Seibel, 2008; Baumann et al., 2012). Exposure to elevated $\mathrm{CO}_{2}$ particularly affects calcifying organisms (Orr et al., 2005; Dupont et al., 2008; Fabry et al., 2008; Talmage and Gobler, 2010), although detrimental effects on survival, growth and respiratory physiology of non-calcifying marine animals have also been observed (Seibel and Walsh, 2001; Rosa and Seibel, 2008; Munday et al., 2009b).

Fish have developed an effective acid-base regulatory mechanism, which allows them to accumulate bicarbonate and exchange ions across gills under hypercapnic conditions (Pörtner et al., 2005; Ishimatsu et al., 2008; Melzner et al., 2009). While this is true for adult organisms, early life stages may not benefit from it, as they lack well-developed and specialized ion-regulatory mechanisms to regulate and maintain their internal ionic environment (Morris, 1989; Sayer et al., 1993). Therefore, early life stages are expected to be the most vulnerable to ocean climate-change-related conditions and their eventual inability to cope and adapt may constitute a bottleneck for species persistence in a changing ocean (Bauman et al., 2012; Frommel et al., 2012). Until now, only a few studies have scrutinized the impact of ocean climate change on fish larvae performance. While some report negligible effects of ocean acidification on fish larvae (Munday et al., 2011b; Hurst et al., 2012; Harvey et al., 2013; Hurst et al., 2013; Maneja et al., 2013), others demonstrate that ocean warming and acidification may have a direct impact on embryonic development, larval growth, metabolism, behavior and survival (Bauman et al., 2012; Franke and Clemmesen, 2011; Frommel et al., 2012; Bignami et al., 2013; Pimentel et al., 2014). More recently, it has also been shown that larval otoliths can be affected by changes in seawater carbonate chemistry (Checkley et al., 2009; Munday et al., 2011a; Bignami et al., 2013), but the impact of hypercapnia on larval fish skeletogenesis still remains unclear.

In the present study, we investigated how the combined effect of warming $\left(+4^{\circ} \mathrm{C}\right)$ and high partial pressure of $\mathrm{CO}_{2}\left(\mathrm{pCO}_{2} ; 0.16 \%\right.$ $\left.\mathrm{CO}_{2}, \sim 1600 \mu \mathrm{atm}, \Delta \mathrm{pH}=0.5\right)$ affects the hatching success, larval survival, growth, metabolic rates, thermal tolerance limits and skeletogenesis of early life stages of a flatfish, Solea senegalensis Kaup 1858, with major commercial importance. This teleost fish is an environmentally resilient species that inhabits the Western Iberian Upwelling Ecosystem, the northern limit of the Canary Current Upwelling System, one of the four major eastern boundary currents 
of the world, where $p \mathrm{CO}_{2}$ levels may reach up to $~ 500 \mu \mathrm{atm}$ (Álvarez-Salgado et al., 1997; Pérez et al., 1999; Borges and Frankignoulle, 2002). Thus, organisms inhabiting such upwelling ecosystem are commonly exposed to seasonal high $p \mathrm{CO}_{2}$ events, because of the emergence of deep hypercapnic water masses. In these regions, the future $p \mathrm{CO}_{2}$ levels are thus expected to exceed the forecasted $1000 \mu \mathrm{atm}$ for 2100 (Meehl et al., 2007).

\section{RESULTS}

\section{Hatching success, larval growth and survival}

The impact of high $p \mathrm{CO}_{2}$ and environmental warming on the hatching success, survival, length and growth of $S$. senegalensis larvae is shown in Fig. 1 (see also supplementary material Table S1). Warming had a significant negative impact on the hatching success of sole larvae $(P<0.05)$, but neither hypercapnia $(P>0.05)$ nor the interaction between hypercapnia and warming had a significant effect $(P>0.05)$. The hatching rates decreased from $86.7 \pm 5.8 \%$ at the present-day scenario to $70.0 \pm 10.0 \%$ under the future hypercapnic and warming conditions (Fig. 1A).

Survival rates of 30 days post hatching (dph) larvae were also significantly affected (Fig. 1B). Both temperature and $p \mathrm{CO}_{2}$ had a significant effect $(P<0.001)$ on survivorship, which decreased from $45.7 \pm 1.9 \%$ under control conditions to $32.7 \pm 2.6 \%$ in the future scenario. However, the interaction between the two variables was not significant $(P>0.05)$. The mean length of 30 dph larvae under control conditions was $13.2 \pm 1.5 \mathrm{~mm}$ (Fig. 1C). Larval growth increased significantly with warming $(P<0.05)$, but decreased significantly under acidified conditions $(P<0.05)$, with an observed significant interaction effect between these two variables $(P<0.05)$. Warming was responsible for increasing length by 48.6 and $46.5 \%$ under normocapnic and hypercapnic conditions, respectively. Regardless of temperature, $S$. senegalensis larvae became nearly $22 \%$ smaller with increasing $\mathrm{CO}_{2}$. As a result, the highest length value $(19.4 \pm 1.1 \mathrm{~mm})$ was observed under the warming and normocapnic scenario, while the lowest length $(10.3 \pm 0.9 \mathrm{~mm})$ was found at lower temperature and hypercapnic conditions. An almost identical trend was observed for specific growth rate, which presented a $23.7-28.4 \%$ increase with warming and an $11.9-15.1 \%$ decrease with acidification (Fig. 1D). No significant effect of the interaction between these two factors was observed $(P>0.05)$.

\section{Oxygen consumption rates, thermal sensitivity and thermal tolerance limits}

The effect of warming and high $p \mathrm{CO}_{2}$ on the metabolic rates and thermal tolerance limits of $S$. senegalensis larvae is presented in Fig. 2 (see also supplementary material Table S2). Temperature had a positive effect $(P<0.05)$ on oxygen consumption rates $(\mathrm{OCR})$, upper thermal tolerance limits $\left(\mathrm{LT}_{50}\right)$ and critical thermal maximum $\left(\mathrm{CT}_{\max }\right)$, while hypercapnic conditions promoted a significant reduction $(P<0.05)$ of these physiological parameters. Even so, no significant effect of the interaction between these two factors was observed $(P>0.05)$. The OCR of $30 \mathrm{dph}$ larvae increased with temperature from $23.1 \pm 3.2$ to $34.8 \pm 3.5 \mu \mathrm{mol} \mathrm{O}_{2} \mathrm{~h}^{-1} \mathrm{~g}^{-1}$ and from $16.8 \pm 3.8$ to $25.3 \pm 1.5 \mu \mathrm{mol} \mathrm{O}_{2} \mathrm{~h}^{-1} \mathrm{~g}^{-1}$ under normocapnic and hypercapnic conditions, respectively (Fig. 2A). These findings represent a decrease of $27.3 \%$ under acidified conditions. The $\mathrm{LT}_{50}$ of $30 \mathrm{dph}$ larvae increased with temperature from $37.5 \pm 0.1$ to $37.7 \pm 0.0^{\circ} \mathrm{C}$ under normocapnia, and from $36.1 \pm 0.1$ to $38.8 \pm 0.3^{\circ} \mathrm{C}$ under hypercapnia conditions (Fig. 2B). The $\mathrm{CT}_{\max }$ of $30 \mathrm{dph}$ larvae followed a similar pattern as for OCR and $\mathrm{LT}_{50}$, increasing with temperature from $37.0 \pm 0.9$ to $38.3 \pm 0.5^{\circ} \mathrm{C}$ under normocapnia, and from $35.5 \pm 0.6$ to $37.3 \pm 0.7^{\circ} \mathrm{C}$ under hypercapnia (Fig. 2C). Additionally, the development stage had a significant effect $(P<0.05)$ on metabolic rates and thermal tolerance limits. Solea senegalensis hatchlings presented higher OCR and lower $\mathrm{LT}_{50}$ and $\mathrm{CT}_{\max }$ values in comparison to $30 \mathrm{dph}$ larvae (Fig. 2).

Thermal sensitivity $\left(Q_{10}\right)$ of $S$. senegalensis larvae between 18 and $22^{\circ} \mathrm{C}$ ranged between 1.89 and 2.79 (Table 1). $Q_{10}$ values decreased under acidified conditions and increased with fish age.

\section{Skeletal deformities and otolith morphometrics}

Several types of skeletal anomalies were found in $30 \mathrm{dph} S$. senegalensis larvae (Table 2, Fig. 3). Skeletal deformities consisted mainly of vertebral abnormalities, such as fusions (Fig. 3C-G), body
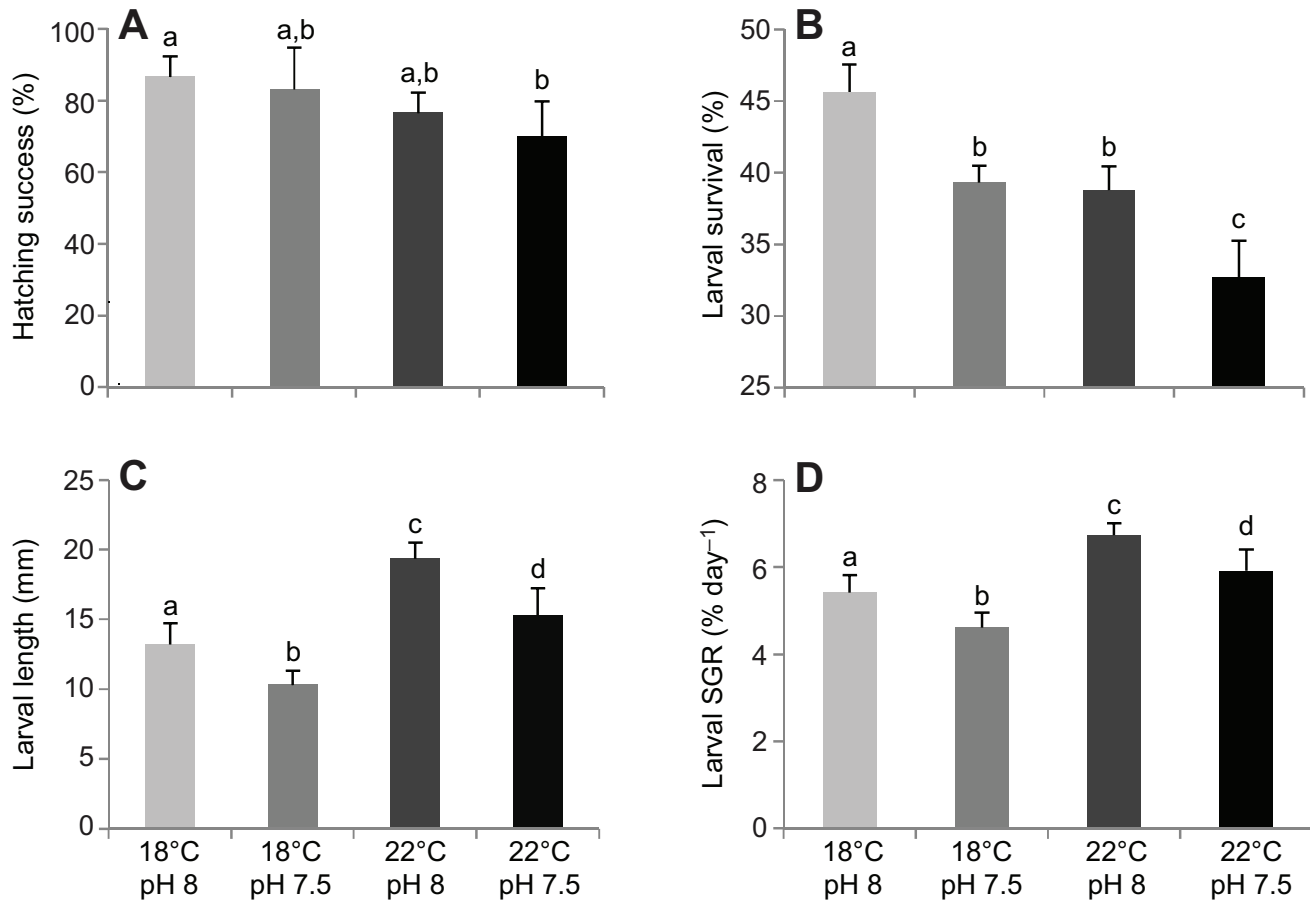

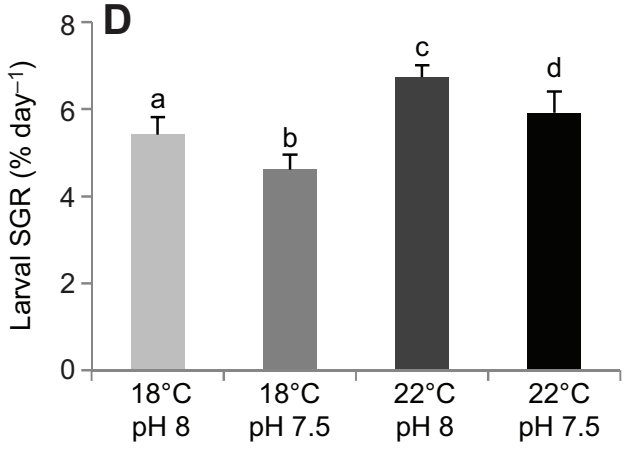

Fig. 1. Effect of ocean warming and acidification on the early life stages of Solea senegalensis. (A) Hatching success $(n=30)$, (B) survival rate $(n=3)$, (C) standard length $(n=60)$ and (D) specific growth rate (SGR) $(n=60)$ of 30 days post hatching (dph) larvae at different temperature and $\mathrm{pH}$ scenarios. Values are given as means \pm s.d. Different letters represent significant differences between the different climate scenarios $(P<0.05)$ (more statistical details are available in supplementary material Table S1). 

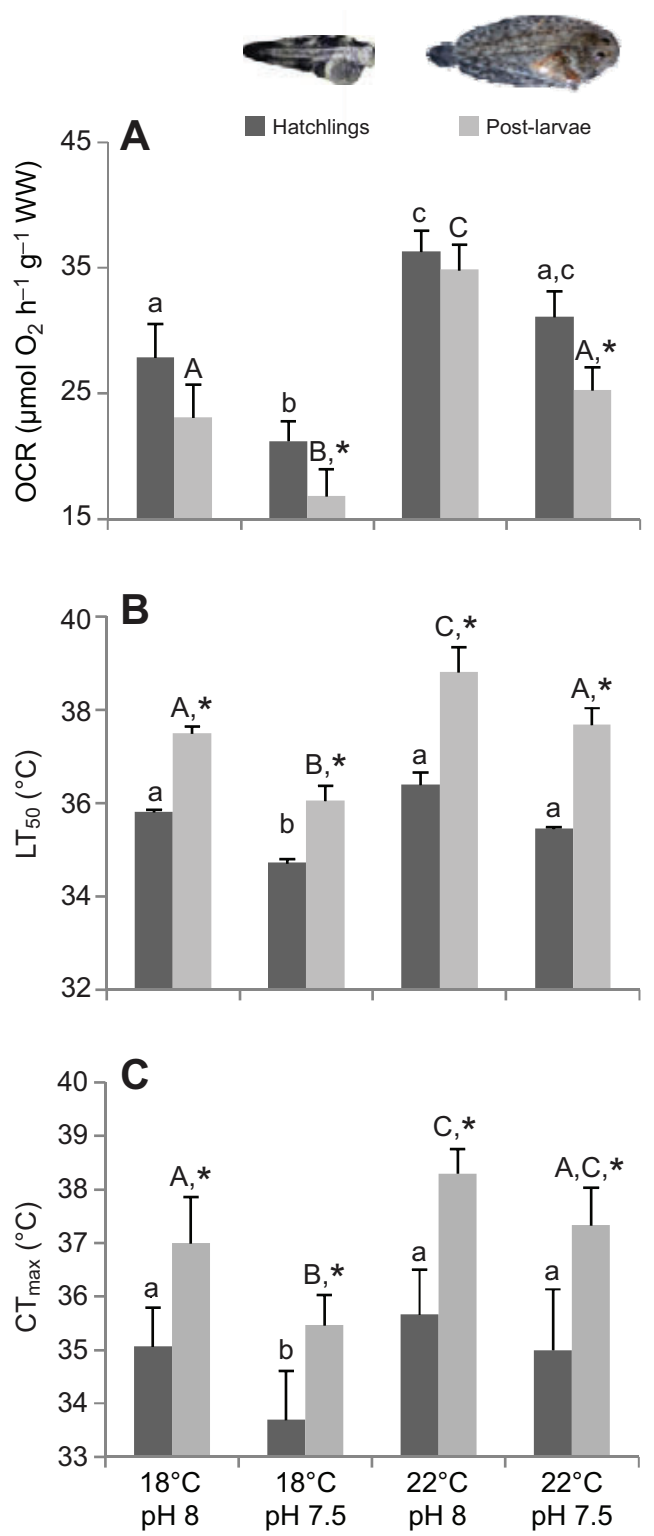

Fig. 2. Impact of ocean warming and acidification on the metabolism and thermal tolerance of Solea senegalensis larvae. (A) Oxygen consumption rates (OCR) $(n=9)$, (B) upper thermal tolerance limits $\left(\mathrm{LT}_{50}\right)$ $(n=30)$ and $(C)$ critical thermal maximum $\left(\mathrm{CT}_{\max }\right)(n=30)$ of 0 and 30 ph larvae (dark and light gray, respectively) at different temperature and $\mathrm{pH}$ scenarios. Values are given as means \pm s.d. Different letters (lowercase for hatchlings; uppercase for post-larvae) represent significant differences between the different climate scenarios $(P<0.05)$. Asterisks represent significant differences between the two developmental stages $(P<0.05)$ (more statistical details are available in supplementary material Table S2)

malformations (Fig. 3C,D), and vertebral curvatures such as scoliosis, lordosis and kyphosis (Fig. 3I,J). Structures such as haemal and neural spines and arches were some of the most affected structures across treatments (Fig. 3C-G).

Future ocean warming and high $p \mathrm{CO}_{2}$ conditions had a significant effect on the incidence of skeletal deformities in $S$. senegalensis larvae (Figs 4, 5; see also supplementary material Table S3). Rising temperature and $\mathrm{CO}_{2}$ levels increased the frequency of total skeletal deformities (Fig. 4A), from $70.9 \pm 2.6 \%$ at the present-day scenario to $93.2 \pm 2.7 \%$ under the future conditions $(P<0.05)$, an increase of $31.5 \%$. No cranium or pectoral fin deformities were observed under
Table 1. Thermal sensitivity $\left(Q_{10}\right)$ between 18 and $22^{\circ} \mathrm{C}$ of 0 and 30 days post hatching (dph) Solea senegalensis larvae at normocapnia $(\mathrm{pH}=8.0)$ and hypercapnia $(\mathrm{pH}=7.5)$

\begin{tabular}{lll}
\hline Developmental stage & $\mathrm{pH}$ & $\mathrm{Q}_{10}$ \\
\hline $0 \mathrm{dph}$ & 7.5 & 1.89 \\
& 8.0 & 2.62 \\
$30 \mathrm{dph}$ & 7.5 & 2.77 \\
& 8.0 & 2.79 \\
\hline
\end{tabular}

control temperature and $p \mathrm{CO}_{2}$ rearing conditions. Under the future scenario, caudal vertebra was the most affected region (Fig. 4D), followed by cranium (Fig. 4B), caudal fin (Fig. 4E), abdominal vertebra (Fig. 4C), pelvic fin (Fig. 4H), dorsal fin (Fig. 4F), and finally the pectoral fins (Fig. $4 \mathrm{H}$ ). In what concerns severe skeletal deformities, $p \mathrm{CO}_{2}$ was the main factor contributing to the higher proportion of deformities observed in the future scenario (Fig. 5). Under present-day conditions, less than $1.9 \%$ of the larvae presented severe vertebral curvatures such as scoliosis (Fig. 5B) or lordosis (Fig. 5C), and no kyphotic larvae were observed (Fig. 5D). In contrast, all types of severe anomalies significantly increased $(P<0.05)$ with future environmental predictions, especially with high $p \mathrm{CO}_{2}$. The interaction factor between temperature and $p \mathrm{CO}_{2}$ did not have a significant effect $(P>0.05)$ on the incidence of skeletal deformities (including the severe ones), except for abdominal vertebra and dorsal fin deformities.

Otolith size was also greatly affected by future warming and hypercapnia conditions (Fig. 6; see also supplementary material Table S1). Solea senegalensis larvae experienced a 109.3\% increase in otolith area with increasing temperature and $p \mathrm{CO}_{2}(P<0.05)$. Otolith area increased from $1063.6 \pm 398.8 \mathrm{~mm}^{2}$ under the presentday conditions to $1994.5 \pm 234.5 \mathrm{~mm}^{2}$ under warming, and then to $2226.2 \pm 187.0 \mathrm{~mm}^{2}$ under the combined effect of rising temperature and $p \mathrm{CO}_{2}$. However, the interaction of both factors was not significant $(P>0.05)$.

\section{DISCUSSION}

The future predictions of ocean warming and acidification were revealed to have a negative impact on several aspects of the early ontogeny of the environmentally resilient flatfish $S$. senegalensis. Despite the short embryonic development time of this species (less than 2 days), the warming experienced during egg incubation was enough to elicit a negative effect on hatching success. Hatching rates decreased 16.7 percentage points with warming and acidification, in comparison to the present-day conditions. Moreover, the high temperature and $p \mathrm{CO}_{2}$ levels had a further negative effect on larval survival, representing a decrease of 28.4 percentage points in relation to the present scenario.

As expected, larval growth greatly increased with warming. Increased temperature was responsible for increasing length by $46.5-48.6 \%$. Nevertheless, it is important to keep in mind that this increment does not reflect differences in size at a specific stage of development, as development is accelerated at higher temperatures. In contrast, larval growth decreased under high $p \mathrm{CO}_{2}$ levels. Contrary to some studies that have shown that larvae can become bigger under high $p \mathrm{CO}_{2}$ conditions (Munday et al., 2009a; Hurst et al., 2012; Hurst et al., 2013), S. senegalensis larvae became almost $25 \%$ smaller with increasing $p \mathrm{CO}_{2}$.

An almost identical trend was observed for larval metabolic rates and thermal tolerance limits. While temperature had a positive effect on OCR (within normal $Q_{10}$ values) and thermal tolerance limits, hypercapnic conditions triggered a significant reduction in such 
Table 2. Types of skeletal deformities considered in this study (adapted from Wagemans et al., 1998; Gavaia et al., 2002; Dionísio et al., 2012)

\begin{tabular}{|c|c|c|}
\hline Affected area & Types of skeletal deformities & Description \\
\hline \multirow[t]{3}{*}{ Cranium } & Jaw deformities & Malformed and/or reduced maxillary, premaxillary, angular and/or dentary bones \\
\hline & Ocular migration deformities & Incomplete or non-existent ocular migration \\
\hline & Deformed opercle & Deformed opercular, ceratobranchial and ceratohyal bones \\
\hline \multirow[t]{9}{*}{ Abdominal vertebra } & Vertebral body malformation & Torsion and/or malformation of one or more vertebrae \\
\hline & Vertebral fusion & Partial or total fusion of two or more vertebrae \\
\hline & Vertebral compression & Partial or total compression of two or more vertebrae \\
\hline & Malformed neural and/or haemal arch & Deformed, absent or fused \\
\hline & Malformed neural and/or haemal spine & Deformed, absent or fused \\
\hline & Malformed parapophysis & Deformed, absent, fused or supernumerary \\
\hline & Scoliosis & Side-to-side vertebral curvature \\
\hline & Lordosis & Excessive inward vertebral curvature \\
\hline & Kyphosis & Excessive outward vertebral curvature \\
\hline \multirow[t]{7}{*}{ Caudal vertebra } & Vertebral body malformation & Torsion and/or malformation of one or more vertebrae \\
\hline & Vertebral fusion & Partial or total fusion of two or more vertebrae \\
\hline & Vertebral compression & Partial or total compression of two or more vertebrae \\
\hline & Malformed neural and/or haemal arch & Deformed, absent, asymmetric or fused \\
\hline & Malformed neural and/or haemal spine & Deformed, absent, asymmetric or fused \\
\hline & Scoliosis & Side-to-side vertebral curvature \\
\hline & Lordosis & Excessive inward vertebral curvature \\
\hline \multirow[t]{4}{*}{ Caudal fin complex } & Malformed hypural & Deformed, absent, asymmetric, fused or supernumerary \\
\hline & Malformed epural & Deformed, absent, asymmetric, fused or supernumerary \\
\hline & Malformed parahypural & Deformed, absent, asymmetric, fused or supernumerary \\
\hline & Malformed fin rays & Deformed, absent, asymmetric, fused or supernumerary \\
\hline \multirow[t]{2}{*}{ Dorsal fin } & Malformed fin rays & Deformed, absent, asymmetric, fused or supernumerary \\
\hline & Malformed pterygiophores & Deformed, absent, fused or supernumerary \\
\hline Pectoral/pelvic fin & Malformed fin rays & Deformed, absent, asymmetric, fused or supernumerary \\
\hline
\end{tabular}

physiological parameters. Additionally, and as expected, massspecific metabolic rates decreased with development, while thermal tolerance limits revealed an opposite ontogenetic trend, i.e. older larvae revealed higher thermal tolerance limits than newly hatched ones. We presume that exposure to higher $p \mathrm{CO}_{2}$ might have impaired acid-base balance regulation, which directly affects the efficiency of cellular activities (Pörtner et al., 2005; Perry and Gilmour, 2006) and may cause deleterious effects on larval physiology and growth.

Faster growth at higher temperatures could have some advantages, because slower growing larvae are potentially more vulnerable to predators and may thus experience greater mortality (Anderson, 1988). Nevertheless, growth enhancement with temperature might also present some disadvantages, because faster larval growth was accompanied by an increase in the incidence of skeletal deformities. Indeed, temperature is known to be one of the most important environmental factors that can induce morphological deformities during fish development (Aritaki and Seikai, 2004; Georgakopoulou et al., 2010; Dionísio et al., 2012). Additionally, $\mathrm{pH}$ may also affect the prevalence of fish skeletal deformities (Lall and Lewis-McCrea, 2007). Although fish skeleton is predominantly composed of calcium phosphate (in the form of hydroxyapatite and cartilaginous material) (Lall and Lewis-McCrea, 2007), additional buffering of tissue $\mathrm{pH}$ with bicarbonate and non-bicarbonate ions is expected under acidified conditions, which may interfere with larval skeletal development. In this study, the future warming and high $p \mathrm{CO}_{2}$ scenario was responsible for increasing the incidence of total skeletal deformities by 22.2 percentage points, affecting $93.1 \%$ of the larvae. Moreover, high $p \mathrm{CO}_{2}$ was the main factor responsible for the increase of severe skeletal deformities in flatfish larvae. Under the present-day conditions, less than $1.9 \%$ of the larvae presented vertebral curvature deformities such as scoliosis or lordosis, and no kyphotic larvae were observed. In contrast, more than $50 \%$ of the larvae under the future environmental scenario presented vertebral curvature deformities. These findings, however, are in disagreement with a recent study that found no effects of $\mathrm{CO}_{2}$ on the skeletal development of a reef fish (Munday et al., 2011b).

However, the higher incidence of malformations under the future scenario should be carefully interpreted. The high percentage of skeletal deformities found in $S$. senegalensis under control temperature and $p \mathrm{CO}_{2}$ conditions $(70.9 \pm 2.7 \%$ ), although similar to the values commonly found for this species under intensive rearing conditions (Fernández et al., 2009; Dionísio et al., 2012), may indicate that fish were potentially stressed in captivity and would, therefore, be more susceptible to the negative effects of higher temperature and $\mathrm{CO}_{2}$ levels. Nevertheless, this fact does not exclude the amplifying effect that warming and hypercapnia had on the incidence of skeletal deformities. Even though the increase may be overestimated, the higher rate of malformations in captive larvae under high temperature and $p \mathrm{CO}_{2}$ conditions may provide an insight into how future warming and acidification may impact the development of wild flatfish larvae and their future performance in a changing ocean.

Skeletal deformities may impair the ecophysiological performance of fish larvae in many different ways. Vertebral curvatures and fin deformities may affect larval swimming behavior, feeding efficiency and the capacity to maintain their position in a current (Powell et al., 2009). Additionally, larvae with cranium deformities, such as ocular migration anomalies, probably will have their capability to feed, attack prey and avoid predators affected. Larvae with operculum deformities may increase gill's susceptibility to fungus, bacteria and amoebic parasitic infections (Powell et al., 2008) and, as a result, their swimming and cardiovascular performance might be compromised (Powell et al., 2008; Lijalad and Powell, 2009; Powell et al., 2009). Additionally, fish with dental, premaxillar or maxillar deformities cannot adduct their mandible and, besides having potential feeding restrictions, the buccal-opercular pumping of water across gills is also likely to be impaired and compromised (Lijalad and Powell, 2009). 

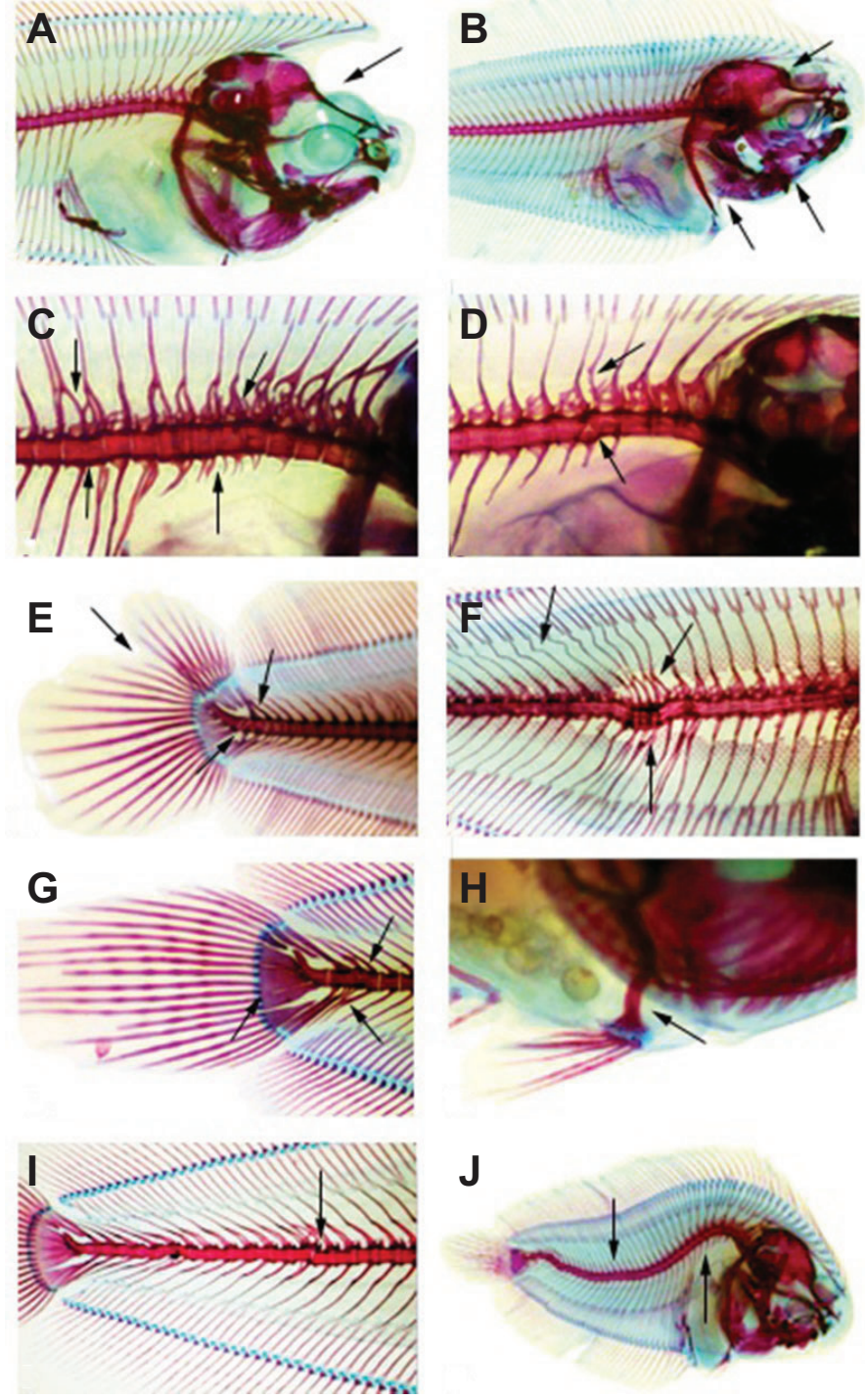

Fig. 3. Skeletal deformities of $\mathbf{3 0} \mathrm{dph}$ Solea senegalensis larvae under the effects of ocean warming and acidification. (A) Cranium deformity, ocular migration anomaly; (B) opercle and cranium deformity; (C) vertebra fusion and compression, deformed spines, arches and parapophysis; (D) vertebra fusion and deformed spines and arches; (E) vertebra fusion, urostyle fusion and caudal fin complex anomalies such as modified neural and hemal spine, hypural and fin rays; (F) vertebra fusion and compression, deformed spines and arches; $(G)$ vertebral fusion, deformed hypural and modified hemal spines; $(\mathrm{H})$ pelvin fin deformity; (I) scoliosis; (J) lordosis and kyphosis.

In addition to skeletal deformities, $S$. senegalensis larvae under this future climate change scenario will also be affected by changes in otolith size. Solea senegalensis larvae experienced a $109.3 \%$ increase in otolith area with rising temperature and $p \mathrm{CO}_{2}$. Although otoliths are calcified structures composed of aragonite-protein bilayers, recent studies revealed that $\mathrm{pH}$ regulation in otolith endolymph may lead to increased precipitation of calcium carbonate in otoliths of fingerlings exposed to elevated $\mathrm{CO}_{2}$ (Checkley et al., 2009; Munday et al., 2011a; Bignami et al., 2013). However, this is not a rule among fishes. In at least one coral reef fish species, otolith size was not affected by exposure to elevated $p \mathrm{CO}_{2}$ (Munday et al., 2011b). Otoliths are used by fish for orientation, perception and acceleration, and to maintain postural equilibrium. Thus, changes in otolith size may have implications for their ecological performance, behavior and individual fitness (Gagliano et al., 2008; Bignami et al., 2013).

In conclusion, the results presented in our study provide comprehensive insight into the combined effects of ocean warming and hypercapnic conditions on $S$. senegalensis larval development. Fish larval stages represent a critical life phase for species' ecological success. Therefore, climate-change-related impairments in metabolism, thermal tolerance, growth, skeletal development and survival may lead to substantial declines in adult populations, putting in jeopardy the species' persistence under a climate change scenario.

\section{MATERIALS AND METHODS}

\section{Egg collection and incubation}

Solea senegalensis eggs were obtained from a wild-caught broodstock of four females and two males, under natural spawning conditions at Instituto Português do Mar e da Atmosfera (IPMA), Centro Regional de Investigação Pesqueira do Sul (CRIPSul, Olhão, Portugal), during June 2012. After collection, eggs were transported and immediately transferred, under environmentally controlled conditions, to the aquaculture facilities in Laboratório Marítimo da Guia (Cascais, Portugal). To estimate the potential physiological responses of early life stages to climate change, $S$. senegalensis eggs and larvae were acclimated for 1 month at: (1) $18^{\circ} \mathrm{C}-$ control temperature, the mean sea surface temperature in summer (sSST) and normocapnia $\left(0.04 \% \mathrm{CO}_{2}, p \mathrm{CO}_{2}=\sim 400 \mu \mathrm{atm}, \mathrm{pH}=8.0\right)$; (2) $18^{\circ} \mathrm{C}$ and hypercapnia $\left(0.16 \% \mathrm{CO}_{2}, p \mathrm{CO}_{2}=\sim 1600 \mu \mathrm{atm}, \Delta \mathrm{pH}=0.5, \mathrm{pH}=7.5\right)$; (3) $22^{\circ} \mathrm{C}$ - the future sSST warming scenario for the western coast of Portugal in $2100\left[+4^{\circ} \mathrm{C}\right.$ above the average sSST (Meehl et al., 2007)] - and normocapnia; and (4) $22^{\circ} \mathrm{C}$ and hypercapnia. Prior to releasing the eggs in the rearing tanks, a $2 \mathrm{~h}$ thermal and chemical acclimation was performed.

Eggs and larvae were reared in 12 individual recirculating systems (i.e. three systems per treatment), filled with filtered (series of 20,10, 5 and $0.35 \mu \mathrm{m}$ ) and UV-irradiated natural seawater. Each system comprised a 191 cylindrical shaped tank (larval rearing tank) connected to a 1001 sump. All rearing tanks were placed inside 4001 water bath tanks (see supplementary material Fig. S1), where temperatures $\left(18.0 \pm 0.2\right.$ and $\left.22.0 \pm 0.2^{\circ} \mathrm{C}\right)$ were maintained and controlled via seawater chillers (HC-1000A, Hailea, Guangdong, China), in order to ensure thermo-controlled conditions.

The photoperiod was set at $14 \mathrm{~h}: 10 \mathrm{~h}$ light:dark. Water filtration was performed through mechanical (glass wool), physical (protein skimmer, Schuran, Jülich, Germany) and biological (ouriço ${ }^{\circledR}$ bioballs, Fernando Ribeiro, Portugal) filters, as well as UV sterilization (TMC, Chorleywood, UK). Throughout the experiment, ammonia and nitrite levels were monitored daily and kept below detectable levels. Temperatures were controlled via seawater chillers (Frimar, Fernando Ribeiro, Portugal), while pH was adjusted automatically via a Profilux system (GHL, Kaiserslautern, Germany) connected to $\mathrm{pH}$ probes (WaterTech $\mathrm{pH}$ 201S) in the rearing tanks and to a standard solenoid valve system connected to a $\mathrm{CO}_{2}$ tank. Any seawater $\mathrm{pH}$ modifications initiated $\mathrm{CO}_{2}$ addition (if the $\mathrm{pH}$ increased) or $\mathrm{CO}_{2}$ filtered air injection (if the $\mathrm{pH}$ decreased), until $\mathrm{pH}$ returned to the set value. Additionally, temperature and $\mathrm{pH}$ were controlled daily using a digital thermometer (Ebro thermometer TFX430) and a portable $\mathrm{pH}$ meter (SevenGo pro $^{\mathrm{TM}} \mathrm{SG} 8$, Mettler Toledo). Mean values were $18.0 \pm 0.2$ and $22.0 \pm 0.2^{\circ} \mathrm{C}$ for temperature and $8.02 \pm 0.05$ and $7.51 \pm 0.05$ for $\mathrm{pH}$. Salinity was kept at $35.4 \pm 0.4$. Seawater carbonate system speciation (Table 3 ) was calculated weekly from total alkalinity [determined according to Sarazin (Sarazin et al., 1999)] and pH measurements. Bicarbonate and $p \mathrm{CO}_{2}$ values were calculated using the CO2SYS program (Lewis and Wallace, 1998), with dissociation constants from Mehrbach et al. (Mehrbach et al., 1973) as refitted by Dickson and Millero (Dickson and Millero, 1987).

\section{Larval rearing}

Newly hatched larvae were randomly placed into rearing tanks (191 volume each) at a stocking density of 70 larvae per liter. All larvae were reared until $30 \mathrm{dph}$ under the different experimental conditions. The feeding schedule was based on larval development under each set of experimental conditions. Larvae opened their mouth at approximately $2 \mathrm{dph}$ and started to feed on 

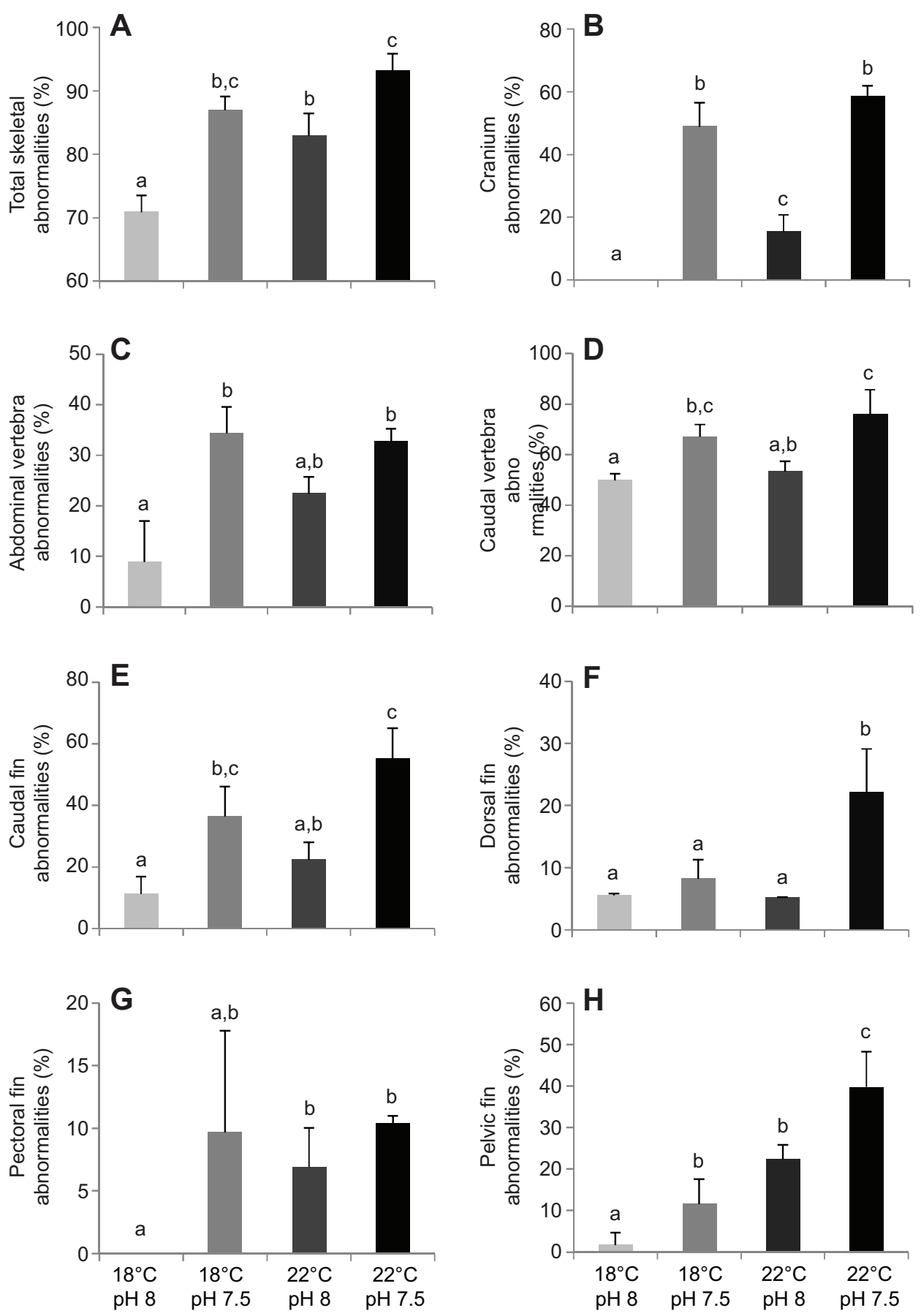

Fig. 4. Incidence of skeletal deformities in Solea senegalensis larvae under the effects of ocean warming and acidification. (A) Total skeletal deformities of $30 \mathrm{dph}$ larvae at different temperature and $\mathrm{pH}$ scenarios, which include deformities in the (B) cranium, (C) abdominal vertebra, (D) caudal vertebra, (E) caudal fin complex, $(F)$ dorsal fin, $(G)$ pectoral fin and $(\mathrm{H})$ pelvic fin. Values are given as means \pm s.d. $(n=60)$. Different letters represent significant differences between the different climate change scenarios $(P<0.05)$ (more statistical details are available in supplementary material Table S3). rotifers, Brachionus plicatilis, at a density of 5 to 10 rotifers $\mathrm{ml}^{-1}$. Live enriched (AlgaMac-3050) Artemia metanauplii were introduced at $5 \mathrm{dph}$ and their proportion was gradually increased from 0.5 to 12 metanauplii $\mathrm{ml}^{-1}$, becoming the only prey offered at $8 \mathrm{dph}$. Frozen metanauplii were also introduced as feed after larval settlement.

\section{Hatching success, larval growth and survival}

Hatching success was analyzed in small rearing boxes placed inside the rearing tanks (one per rearing system). In the beginning of the experiment, a total of 10 eggs (per box) were randomly placed inside each of the 12 boxes (three per treatment), and these were followed throughout the embryonic development. The hatching success was calculated as the percentage of eggs that hatched to normal larvae.

At 0 and $30 \mathrm{dph}, 20$ larvae per tank (60 larvae per treatment) were randomly sampled and their standard length was measured from the anterior extremity to the urostyle flexion, by means of stereoscopic microscope observations (Leica S6D, Leica Microsystems). The standard length of newly hatched larvae was $2.57 \pm 0.13 \mathrm{~mm}$. The specific embryonic growth rate (SGR) was calculated as:

$$
\text { SGR }=\frac{\left[1 \mathrm{n} \text { embryo size }\left(T_{2}\right)-1 \mathrm{n} \text { embryo size }\left(T_{1}\right)\right]}{\text { number of days elapsed between } T_{1} \text { and } T_{2}} \times 100 .
$$

The survival rate was calculated as the percentage of surviving fish by the end of the experiment, with respect to the number of larvae at the beginning of the trial minus those individuals removed for sampling.

\section{Oxygen consumption rates, thermal sensitivity and thermal} tolerance limits

Oxygen consumption measurements were determined according to previously established methods (Pimentel et al., 2012; Rosa et al., 2012). Nine newly 

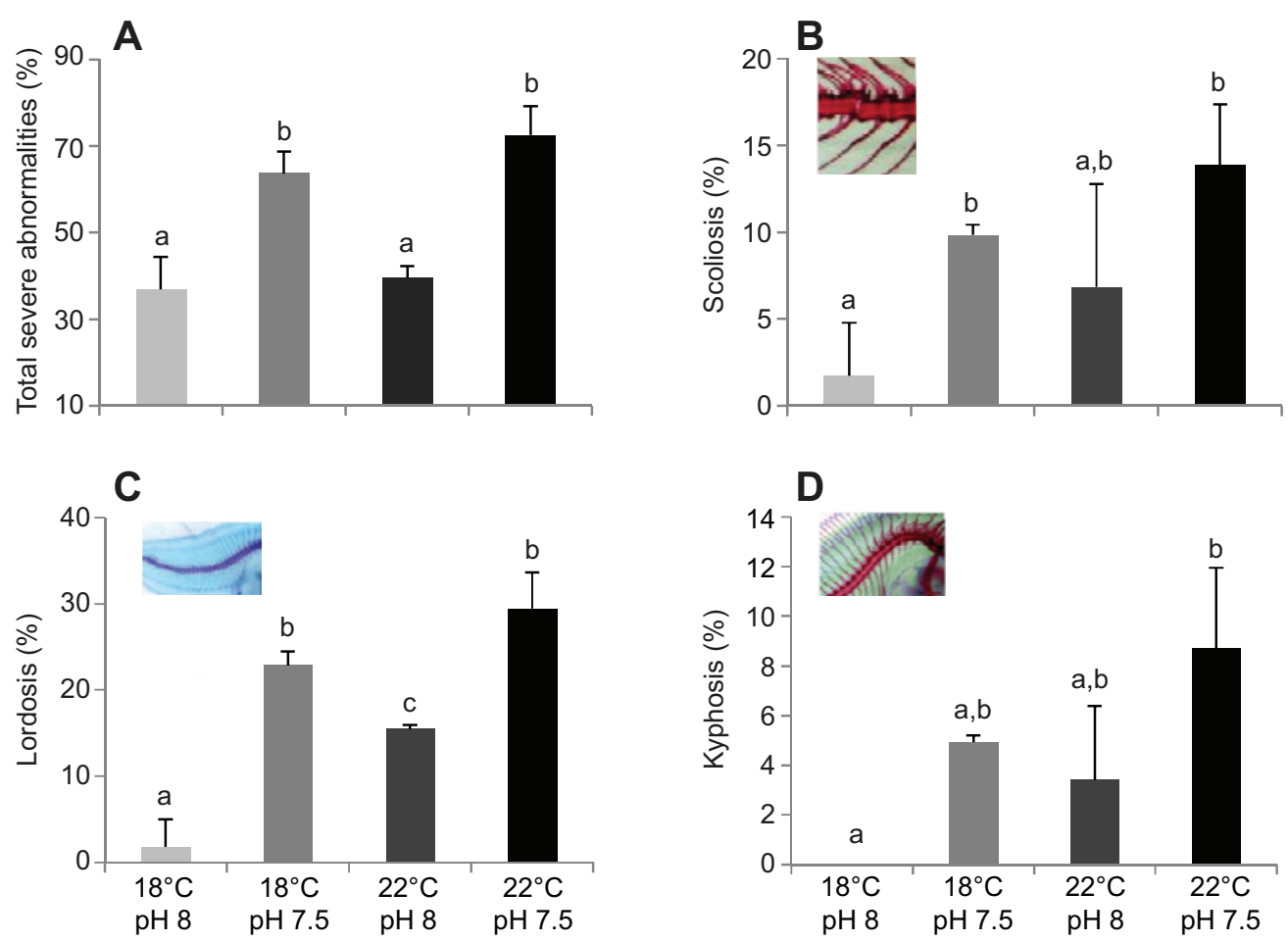

Fig. 5. Incidence of severe skeletal deformities in Solea senegalensis larvae under the effect of ocean warming and acidification. (A) Total severe skeletal deformities and severe vertebral curvatures, such as (B) scoliosis, (C) lordosis and (D) kyphosis of $30 \mathrm{dph}$ larvae at different temperature and $\mathrm{pH}$ scenarios. Values are given as means \pm s.d. $(n=60)$. Different letters represent significant differences between the different climate scenarios $(P<0.05)$ (more statistical details are available in supplementary material Table S3).

hatched ( $0 \mathrm{dph})$ and nine $30 \mathrm{dph}$ larvae were incubated at each of the four treatment conditions, in sealed water-jacketed respirometry chambers (RC300 Respiration Cell, Strathkelvin Instruments Limited, North Lanarkshire, UK) containing $0.35-\mu \mathrm{m}$-filtered and UV-irradiated seawater mixed with antibiotics (50 $\mathrm{mg} \mathrm{l}^{-1}$ streptomycin), in order to avoid bacterial respiration. Water volumes were adjusted in relation to animal mass (up to $10 \mathrm{ml}$ ) in order to minimize locomotion and stress but still allow for spontaneous and routine activity of the hatchlings. Controls (blanks) were used to correct for possible bacterial respiratory activity. Respiration chambers were immersed in water baths (Lauda, Lauda-Königshofen, Germany) to control temperature. Oxygen concentrations were recorded with Clarke-type $\mathrm{O}_{2}$ electrodes connected to a multi-channel oxygen interface (Model 928, Strathkelvin Instruments). The duration of respiratory runs varied between 3 and $6 \mathrm{~h}$. Thermal sensitivity $\left(Q_{10}\right)$ was determined using the standard equation:

$$
Q_{10}=\frac{R\left(T_{2}\right)^{\frac{10}{\left(T_{2}-T_{1}\right)}}}{R\left(T_{1}\right)},
$$

where $R\left(T_{1}\right)$ and $R\left(T_{2}\right)$ represent the oxygen consumption rates at temperatures $T_{1}$ and $T_{2}$, respectively.

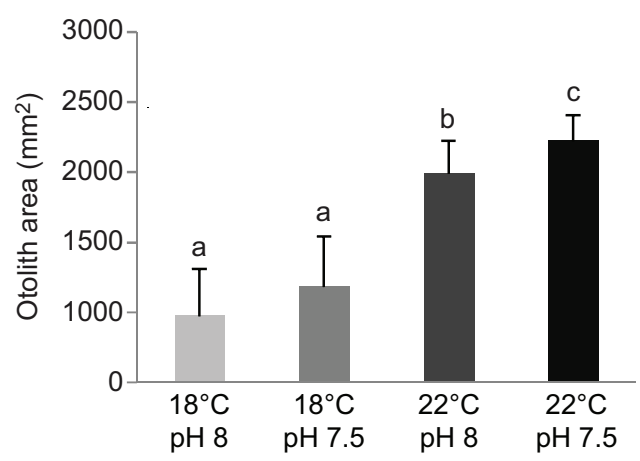

Fig. 6. Effect of ocean warming and acidification on otolith size of $30 \mathrm{dph}$ Solea senegalensis larvae. Otolith area at different temperature and $\mathrm{pH}$ scenarios. Values are given as means \pm s.d. $(n=60)$. Different letters represent significant differences between the different climate scenarios $(P<0.05)$ (more statistical details are available in supplementary material Table S1).
Upper thermal tolerance limits were determined based on previously established methods (Stillman and Somero, 2000). In brief, 0 and $30 \mathrm{dph}$ larvae were incubated in glass containers with $\sim 100 \mathrm{ml}$ of $0.35-\mu \mathrm{m}$-filtered and UV-irradiated seawater collected from the rearing tanks. Each container was stocked with 20 specimens, and a total of three containers were used per experimental treatment. These glass containers were suspended in a temperature-regulated water bath that was controlled to the nearest $0.1^{\circ} \mathrm{C}$. Water bath temperature was set to the acclimation temperature and maintained for $30 \mathrm{~min}$. Thereafter, temperature was increased at a rate of $1{ }^{\circ} \mathrm{C} 30 \mathrm{~min}^{-1}$. Seawater was aerated by means of an air stone and the temperature in each container was checked with thermocouple probes. Every $30 \mathrm{~min}$, if no responsiveness was noticed, the specimen was considered to be dead. The percentage of live individuals at each temperature was calculated, and then transformed by the arcsine square root function and expressed in radians. Linear regression analysis was then used to find the slope of the line, and the temperature at which $50 \%$ of the organisms had died $(0.785 \mathrm{rad})$ was calculated. This was used as a measure of upper thermal tolerance limits and referred to as the $\mathrm{LT}_{50}$. Critical thermal maximum $\left(\mathrm{CT}_{\max }\right)$ was calculated using the equation:

$$
\mathrm{CT}_{\max }=\frac{\Sigma \mathrm{T}_{\text {end-point }}}{n},
$$

where $T_{\text {end-point }}$ is the temperature at which the end-point was reached for each individual ( 1 to $n$ ), and $n$ is the number of individuals in the sample.

\section{Skeletal deformities and otolith morphometrics}

To identify and quantify larval skeletal deformities, 20 larvae per rearing tank (60 larvae per treatment) were randomly sampled and fixed in $4 \%(\mathrm{v} / \mathrm{v})$ buffered paraformaldehyde for $24 \mathrm{~h}$ and then transferred to $70 \%$ ethanol until double stained. Larvae were stained for bone and cartilage using a modification of the method described by Walker and Kimmel (Walker and Kimmel, 2007), and observed under a stereoscopic microscope (Leica S6D, Leica Microsystems) in order to identify skeletal deformities. Skeletal deformities were defined according to previously established methods Fernandez et al., 2009; Dionísio et al., 2012). Deformities were divided into several categories according to the affected structure (e.g. cranium, abdominal vertebra, caudal vertebra, caudal fin, dorsal fin, pectoral fin and pelvic fin), and are described in Table 2. Skeletal deformities such as scoliosis, lordosis, kyphosis, multiple vertebral fusions or more than three anomalies per (Wagemans et al., 1998; Gavaia et al., 2002; Deschamps et al., 2008; 
Table 3. Seawater carbonate chemistry data for the different climate change scenarios

\begin{tabular}{|c|c|c|c|c|c|c|}
\hline Temperature $\left({ }^{\circ} \mathrm{C}\right)$ & $\mathrm{pH}$ (total scale) & $A_{\mathrm{T}}\left(\mu \mathrm{mol} \mathrm{kg}{ }^{-1} \mathrm{SW}\right)$ & $\mathrm{C}_{\mathrm{T}}\left(\mu \mathrm{mol} \mathrm{kg}{ }^{-1} \mathrm{SW}\right)$ & $p \mathrm{CO}_{2}(\mu \mathrm{atm})$ & $\mathrm{HCO}_{3}^{-}\left(\mu \mathrm{mol} \mathrm{kg}{ }^{-1}\right)$ & $\Omega_{\text {arag }}$ \\
\hline $22.02 \pm 0.42$ & $8.03 \pm 0.05$ & $2335.74 \pm 89.09$ & $2148.20 \pm 81.43$ & $424.53 \pm 19.97$ & $1985.25 \pm 75.28$ & $2.24 \pm 0.08$ \\
\hline $22.12 \pm 1.01$ & $7.51 \pm 0.05$ & $2317.40 \pm 36.40$ & $2314.73 \pm 36.72$ & $1654.20 \pm 49.06$ & $2194.88 \pm 34.84$ & $0.78 \pm 0.01$ \\
\hline $18.20 \pm 0.40$ & $8.02 \pm 0.04$ & $2305.70 \pm 80.54$ & $2141.80 \pm 76.78$ & $400.00 \pm 66.71$ & $1993.35 \pm 72.21$ & $1.95 \pm 0.07$ \\
\hline $18.15 \pm 0.29$ & $7.50 \pm 0.03$ & $2281.07 \pm 61.89$ & $2290.90 \pm 62.73$ & $1607.90 \pm 24.78$ & $2173.55 \pm 59.50$ & $0.67 \pm 0.02$ \\
\hline
\end{tabular}

Total carbon $\left(\mathrm{C}_{\mathrm{T}}\right)$, carbon dioxide partial pressure $\left(\mathrm{pCO}_{2}\right)$, bicarbonate concentration $\left(\mathrm{HCO}_{3}{ }^{-}\right)$and aragonite saturation state of seawater $\left(\Omega_{\text {arag }}\right)$ were calculated with CO2SYS using salinity, temperature, $\mathrm{pH}$ and total alkalinity $\left(A_{T}\right)$. Values are means \pm s.d. SW, seawater.

individual were considered severe deformities. Skeletal deformities were quantified as the percentage of fish exhibiting a specific deformity.

In order to analyze otolith area, 20 larvae per rearing tank (60 larvae per treatment) were randomly selected, measured and preserved in absolute ethanol. The left and right sagittal otoliths of each individual were removed and photographed under a stereoscopic microscope (Leica S6D, Leica Microsystems). Otolith area was measured using the ImageJ program. Otolith area was calculated as the mean of the right and left otoliths, and normalized to fish length

\section{Statistical analysis}

ANOVA was used to test for significant differences between the tanks of each experimental treatment. As no differences were found between tanks, all of the samples from the same treatment were pooled and analyzed together. Two-way ANOVAs were then conducted in order to detect significant differences in hatching success, larval survival, standard length, SGR, skeletal deformities and otolith size between temperature and $p \mathrm{CO}_{2}$ treatments. Three-way ANOVA were applied to detect significant differences in OCR, $\mathrm{LT}_{50}$ and $\mathrm{CT}_{\max }$ between temperature and $p \mathrm{CO}_{2}$ treatments and development stage ( 0 and $30 \mathrm{dph})$. Subsequently, post hoc Tukey's honest significant difference tests were performed. All statistical analyses were performed using a significance level of 0.05 , using Statistica 10.0 software (StatSoft Inc., Tulsa, OK, USA).

\section{Acknowledgements}

We thank CRIPSul for supplying fish eggs, and Oceanário de Lisboa and Aquário Vasco da Gama for supplying rotifers and microalgae. We also thank Lloyd Trueblood for helpful suggestions and critically reviewing the manuscript.

\section{Competing interests}

The authors declare no competing financial interests.

\section{Author contributions}

R.R. designed the experiment; M.S.P. and F.F. performed the experiment; M.S.P., F.F., G.D., T.R., P.P., J.M. and R.R. analyzed the data; M.S.P., F.F. and R.R. wrote the main paper. All authors discussed the results and their implications, and commented on the manuscript at all stages.

\section{Funding}

The Portuguese Foundation for Science and Technology (FCT) supported this study through doctoral grants to M.S.P. (SFRH/BD/81928/2011) and G.D. (SFRH/BD/73205/2010), a post-doc grant (SFRH/BPD/79038/2011) to F.F. and project grant to R.R. (PTDC/MAR/0908066/2008 and PTDC/AAG-

\section{GLO/3342/2012)}

\section{Supplementary material}

Supplementary material available online at

http://jeb.biologists.org/lookup/suppl/doi:10.1242/jeb.092635/-/DC1

\section{References}

Álvarez-Salgado, X. A., Castro, C. G., Pérez, F. F. and Fraga, F. (1997). Nutrient mineralization patterns in shelf waters of the Western Iberian upwelling. Cont. Shelf Res. 17, 1247-1270.

Anderson, J. T. (1988). A review of size dependent survival during pre-recruit stages of fishes in relation to recruitment. J. Northwest Atl. Fish. Sci. 8, 55-66.

Aritaki, M. and Seikai, T. (2004). Temperature effects on early development and occurrence of metamorphosis-related morphological abnormalities in hatcheryreared brown sole Pseudopleuronectes herzensteini. Aquaculture 240, 517-530.

Baumann, H., Talmage, S. C. and Gobler, C. J. (2012). Reduced early life growth and survival in a fish in direct response to increased carbon dioxide. Nat. Clim. Change 2, 38-41.
Bignami, S., Sponaugle, S. and Cowen, R. K. (2013). Response to ocean acidification in larvae of a large tropical marine fish, Rachycentron canadum. Glob. Chang. Biol. 19, 996-1006.

Borges, A. V. and Frankignoulle, M. (2002). Distribution of surface carbon dioxide and air-sea exchange in the upwelling system off the Galician coast. Global Biogeochem. Cycles 16, 13.1-13.13.

Byrne, M. (2011). Impact of ocean warming and ocean acidification on marine invertebrate life history stages: vulnerability and potential for persistence in a changing ocean. Oceanogr. Mar. Biol. 49, 1-42.

Byrne, M., Soars, N., Selvakumaraswamy, P., Dworjanyn, S. A. and Davis, A. R. (2010). Sea urchin fertilization in a warm, acidified and high $\mathrm{pCO}_{2}$ ocean across a range of sperm densities. Mar. Environ. Res. 69, 234-239.

Caldeira, K. and Wickett, M. E. (2003). Oceanography: anthropogenic carbon and ocean $\mathrm{pH}$. Nature $425,365-365$

Caldeira, K. and Wickett, M. E. (2005). Ocean model predictions of chemistry changes from carbon dioxide emissions to the atmosphere and ocean. J. Geophys. Res. 110, C09S04.

Carmona-Osalde, C., Rodriguez-Serna, M., Olvera-Novoa, M. A. and GutierrezYurrita, P. J. (2004). Gonadal development, spawning, growth and survival of the crayfish Procambarus llamasi at three different water temperatures. Aquaculture 232, 305-316.

Checkley, D. M., Jr, Dickson, A. G., Takahashi, M., Radich, J. A., Eisenkolb, N. and Asch, R. (2009). Elevated $\mathrm{CO}_{2}$ enhances otolith growth in young fish. Science 324, 1683-1683

Deschamps, M. H., Kacem, A., Ventura, R., Courty, G., Haffray, P., Meunier, F. J. and Sire, J. Y. (2008). Assessment of 'discreet' vertebral abnormalities, bone mineralization and bone compactness in farmed rainbow trout. Aquaculture 279, 1117.

Dickson, A. and Millero, F. (1987). A comparison of the equilibrium constants for the dissociation of carbonic acid in seawater media. Deep Sea Res. A 34, 1733-1743.

Dionísio, G., Campos, C., Valente, L. M. P., Conceicao, L. E. C., Cancela, M. L. and Gavaia, P. J. (2012). Effect of egg incubation temperature on the occurrence of skeletal deformities in Solea senegalensis. J. Appl. Ichthyol. 28, 471-476.

Dupont, S., Havenhand, J., Thorndyke, W., Peck, L. and Thorndyke, M. (2008). Near-future level of $\mathrm{CO}_{2}$-driven ocean acidification radically affects larval survival and development in the brittlestar Ophiothrix fragilis. Mar. Ecol. Prog. Ser. 373, 285294

Fabry, V. J., Seibel, B. A., Feely, R. A. and Orr, J. C. (2008). Impacts of ocean acidification on marine fauna and ecosystem processes. ICES Mar. Res. 65, 414432

Fernández, I., Pimentel, M. S., Ortiz-Delgado, J. B., Hontoria, F., Sarasquete, C., Estevez, A., Zambonino-Infante, J. L. and Gisbert, E. (2009). Effect of dietary vitamin A on Senegalese sole (Solea senegalensis) skeletogenesis and larval quality. Aquaculture 295, 250-265.

Findlay, H. S., Kendall, M. A., Spicer, J. I. and Widdicombe, S. (2010). Relative influences of ocean acidification and temperature on intertidal barnacle post-larvae at the northern edge of their geographic distribution. Estuar. Coast. Shelf Sci. 86, 675-682.

Franke, A. and Clemmesen, C. (2011). Effect of ocean acidification on early life stages of Atlantic herring (Clupea harengus L.). Biogeosciences 8, 3697-3707.

Frommel, A. Y., Maneja, R., Lowe, D., Malzahn, A. M., Geffen, A. J., Folkvord, A., Piatkowski, U., Reusch, T. B. H. and Clemmesen, C. (2012). Severe tissue damage in Atlantic cod larvae under increasing ocean acidification. Nature Clim. Change 2, 42-46.

Gagliano, M., Depczynski, M., Simpson, S. D. and Moore, J. A. Y. (2008). Dispersal without errors: symmetrical ears tune into the right frequency for survival. Proc. $R$. Soc. B 275, 527-534

Gavaia, P. J., Dinis, M. T. and Cancela, M. L. (2002). Osteological development and abnormalities of the vertebral column and caudal skeleton in larval and juvenile stages of hatchery-reared Senegal sole (Solea senegalensis). Aquaculture 211, 305323

Georgakopoulou, E., Katharios, P., Divanach, P. and Koumoundouros, G. (2010). Effect of temperature on the development of skeletal deformities in gilthead seabream (Sparus aurata Linnaeus, 1758). Aquaculture 308, 13-19.

Harvey, B. P., Gwynn-Jones, D. and Moore, P. J. (2013). Meta-analysis reveals complex marine biological responses to the interactive effects of ocean acidification and warming. Ecol. Evol. 3, 1016-1030.

Hurst, T. P., Fernandez, E. R., Mathis, J. T., Miller, J. A., Stinson, C. M. and Ahgeak, E. F. (2012). Resiliency of juvenile walleye pollock to projected levels of ocean acidification. Aquatic Biol. 17, 247-259. 
Hurst, T. P., Fernandez, E. R. and Mathis, J. T. (2013). Effects of ocean acidification on hatch size and larval growth of walleye pollock (Theragra chalcogramma). ICES J. Mar. Sci. 70, 812-822.

Ishimatsu, A., Hayashi, M. and Kikkawa, T. (2008). Fishes in high- $\mathrm{CO}_{2}$, acidified oceans. Mar. Ecol. Prog. Ser. 373, 295-302.

Lall, S. P. and Lewis-McCrea, L. M. (2007). Role of nutrients in skeletal metabolism and pathology in fish - an overview. Aquaculture 267, 3-19.

Langenbuch, M., Bock, C., Leibfritz, D. and Pörtner, H. O. (2006). Effects of environmental hypercapnia on animal physiology: a 13C NMR study of protein synthesis rates in the marine invertebrate Sipunculus nudus. Comp. Biochem. Physiol. 144A, 479-484.

Lewis, E. and Wallace, D. W. R. (1998). CO2SYS - Program Developed for the CO System Calculations, Report ORNL/CDIAC-105. Oak Ridge, TN: Carbon Dioxide Information Analysis Center.

Lijalad, M. and Powell, M. D. (2009). Effects of lower jaw deformity on swimming performance and recovery from exhaustive exercise in triploid and diploid Atlantic salmon Salmo salar L. Aquaculture 290, 145-154

Maneja, R. H., Frommel, A. Y., Geffen, A. J., Folkvord, A., Piatkowski, U., Chang, M. Y. and Clemmesen, C. (2013). Effects of ocean acidification on the calcification of otoliths of larval Atlantic cod Gadus morhua. Mar. Ecol. Prog. Ser. 477, 251-258.

Meehl, G. A., Stocker, T. F., Collins, W. D., Friedlingstein, P., Gaye, A. T., Gregory, J. M., Kitoh, A., Knutti, R., Murphy, J. M., Noda, A. et al. (2007). Climate Change 2007: The Physical Science Basis. Contribution of Working Group I to the Fourth Assessment Report of the Intergovernmental Panel on Climate Change. Cambridge: Cambridge University Press.

Mehrbach, C., Culberson, C., Hawley, J. and Pytkowicz, R. (1973). Measurement of the apparent dissociation constants of carbonic acid in seawater at atmospheric pressure. Limnol. Oceanogr. 18, 897-907.

Melzner, F., Gutowska, M. A., Langenbuch, M., Dupont, S., Lucassen, M. Thorndyke, M. C., Bleich, M. and Pörtner, H. O. (2009). Physiological basis for high $\mathrm{CO} 2$ tolerance in marine ectothermic animals: pre-adaptation through lifestyle and ontogeny? Biogeosciences 6, 2313-2331.

Morris, R. (1989). Acid Toxicity and Aquatic Animals. Cambridge: Cambridge University Press.

Munday, P. L., Donelson, J. M., Dixson, D. L. and Endo, G. G. K. (2009a). Effects of ocean acidification on the early life history of a tropical marine fish. Proc. Biol. Sci. 276, 3275-3283

Munday, P. L., Dixson, D. L., Donelson, J. M., Jones, G. P., Pratchett, M. S. Devitsina, G. V. and Døving, K. B. (2009b). Ocean acidification impairs olfactory discrimination and homing ability of a marine fish. Proc. Natl. Acad. Sci. USA 106, 1848-1852.

Munday, P. L., Hernaman, V., Dixson, D. L. and Thorrold, S. R. (2011a). Effect of ocean acidification on otolith development in larvae of a tropical marine fish. Biogeosciences 8, 1631-1641.

Munday, P. L., Gagliano, M., Donelson, J. M., Dixson, D. L. and Thorrold, S. R. (2011b). Ocean acidification does not affect the early life history development of a tropical marine fish. Mar. Ecol. Prog. Ser. 423, 211-221.

Nilsson, G. E., Crawley, N., Lunde, I. G. and Munday, P. L. (2009). Elevated temperature reduces the respiratory scope of coral reef fishes. Glob. Chang. Biol. 15, 1405-1412

Orr, J. C., Fabry, V. J., Aumont, O., Bopp, L., Doney, S. C., Feely, R. A., Gnanadesikan, A., Gruber, N., Ishida, A., Joos, F. et al. (2005). Anthropogenic ocean acidification over the twenty-first century and its impact on calcifying organisms. Nature 437, 681-686.

Parker, L. M., Ross, P. M. and O'Connor, W. A. (2010). Comparing the effect of elevated $\mathrm{pCO}_{2}$ and temperature on the fertilization and early development of two species of oysters. Mar. Biol. 157, 2435-2452.

Pérez, F. F., Ríos, A. F. and Rosón, G. (1999). Sea surface carbon dioxide off the Iberian Peninsula (North Eastern Atlantic Ocean). J. Mar. Syst. 19, 27-46.
Perry, S. F. and Gilmour, K. M. (2006). Acid-base balance and $\mathrm{CO}_{2}$ excretion in fish: unanswered questions and emerging models. Respir. Physiol. Neurobiol. 154, 199-215.

Pimentel, M. S., Trubenbach, K., Faleiro, F., Boavida-Portugal, J., Repolho, T. and Rosa, R. (2012). Impact of ocean warming on the early ontogeny of cephalopods: a metabolic approach. Mar. Biol. 159, 2051-2059.

Pimentel, M., Pregado, M., Repolho, T. and Rosa, R. (2014). Impact of ocean acidification in the metabolism and swimming behavior of the dolphinfish (Coryphaena hippurus) early larvae. Mar. Biol. 161, 725-729.

Pörtner, H. O. (2008). Ecosystem effects of ocean acidification in times of ocean warming: a physiologist's view. Mar. Ecol. Prog. 373, 203-217.

Pörtner, H. O. and Knust, R. (2007). Climate change affects marine fishes through the oxygen limitation of thermal tolerance. Science 315, 95-97.

Pörtner,, H. O., Langenbuch, M. and Reipschlager, A. (2004). Biological impact of elevated ocean $\mathrm{CO}_{2}$ concentrations: lessons from animal physiology and earth history. J. Oceanogr. 60, 705-718.

Pörtner,, H. O., Langenbuch, M. and Michaelidis, B. (2005). Synergistic effects of temperature extremes, hypoxia, and increases in $\mathrm{CO}_{2}$ on marine animals: from Earth history to global change. J. Geophys. Res. Oceans. 110, C09S10.

Powell, M. D., Leef, M. J., Roberts, S. D. and Jonesk, M. A. (2008). Neoparamoebic gill infections: host response and physiology in salmonids. J. Fish Biol. 73, 21612183.

Powell, M. D., Jones, M. A. and Lijalad, M. (2009). Effects of skeletal deformities on swimming performance and recovery from exhaustive exercise in triploid Atlantic salmon. Dis. Aquat. Organ. 85, 59-66.

Rosa, R. and Seibel, B. A. (2008). Synergistic effects of climate-related variables suggest future physiological impairment in a top oceanic predator. Proc. Natl. Acad. Sci. USA 105, 20776-20780.

Rosa, R., Pimentel, M. S., Boavida-Portugal, J., Teixeira, T., Trübenbach, K. and Diniz, M. (2012). Ocean warming enhances malformations, premature hatching, metabolic suppression and oxidative stress in the early life stages of a keystone squid. PLOS ONE 7, e38282.

Rosa, R., Trübenbach, K., Repolho, T., Pimentel, M., Faleiro, F., Boavida-Portugal, J., Baptista, M., Lopes, V. M., Dionísio, G., Leal, M. C. et al. (2013). Lower hypoxia thresholds of cuttlefish early life stages living in a warm acidified ocean. Proc. Biol. Sci. 280, 20131695.

Rosa, R., Trübenbach, K., Pimentel, M. S., Boavida-Portugal, J., Faleiro, F., Baptista, M., Dionísio, G., Calado, R., Pörtner, H. O. and Repolho, T. (2014). Differential impacts of ocean acidification and warming on winter and summer progeny of a coastal squid (Loligo vulgaris). J. Exp. Biol. 217, 518-525.

Sarazin, G., Michard, G. and Prevot, F. (1999). A rapid and accurate spectroscopic method for alkalinity measurements in sea water samples. Water Res. 33, 290-294

Sayer, M. D. J., Reader, J. P. and Dalziel, T. R. K. (1993). Fresh-water acidification effects on the early-life stages of fish. Rev. Fish Biol. Fish. 3, 95-132.

Seibel, B. A. and Walsh, P. J. (2001). Carbon cycle. Potential impacts of $\mathrm{CO}_{2}$ injection on deep-sea biota. Science 294, 319-320.

Sheppard Brennand, H., Soars, N., Dworjanyn, S. A., Davis, A. R. and Byrne, M. (2010). Impact of ocean warming and ocean acidification on larval development and calcification in the sea urchin Tripneustes gratilla. PLOS ONE 5, e11372.

Stillman, J. H. and Somero, G. N. (2000). A comparative analysis of the upper thermal tolerance limits of eastern Pacific porcelain crabs, genus Petrolisthes: influences of latitude, vertical zonation, acclimation, and phylogeny. Physiol. Biochem. Zool. 73, 200-208.

Talmage, S. C. and Gobler, C. J. (2010). Effects of past, present, and future ocean carbon dioxide concentrations on the growth and survival of larval shellfish. Proc. Natl. Acad. Sci. USA 107, 17246-17251.

Wagemans, F., Focant, B. and Vandewalle, P. (1998). Early development of the cephalic skeleton in the turbot. J. Fish Biol. 52, 166-204.

Walker, M. B. and Kimmel, C. B. (2007). A two-color acid-free cartilage and bone stain for zebrafish larvae. Biotech. Histochem. 82, 23-28. 